\title{
Protocadherin Fat 4
}

National Cancer Institute

\section{Source}

National Cancer Institute. Protocadherin Fat 4. NCI Thesaurus. Code C128256.

Protocadherin Fat 4 (4981 aa, $543 \mathrm{kDa}$ ) is encoded by the human FAT 4 gene. This protein plays a role in cell polarity. 